\title{
EVALUASI PENERAPAN PEMBELAJARAN K13 DI SEKOLAH DASAR DHARMAWATI ARIEF TANGERANG
}

\author{
Ina Magdalena ${ }^{1}$, Nia Hidayatul Maula ${ }^{2}$, Sekar Ayu Amelia ${ }^{3}$, Amelia Ismawati ${ }^{4}$ \\ Universitas Muhammadiyah Tangerang \\ Inapgsd@gmail.com¹, Hidayatul1407@gmail.com²
}

\begin{abstract}
Evaluation is interpreted as a process of collecting systematic analysis and interpretation to determine the extent which students that achieve the learning objectives as stated in curriculum. Curriculum evaluation is intended to examine the overall curriculum performance in terms of various criteria. Performance indicators that are evaluated are not only limited to effectiveness, but also the relevance, efficiency of this program. This research uses qualitative research by using description interviews as a data collection technique. The results show that in this application, teachers still found experience difficulties in the process of learning activities due to lack of optimal teacher training. The implementation of the K13 curriculum was carried out within one week, and only a few teachers took part in the training so that there were no equal teachers who were able to apply the K13 curriculum in the process of teaching activities in primary schools.
\end{abstract}

Keywords: Evaluation, Curriculum K13,Elementary School

\begin{abstract}
Abstrak : Evaluasi dimaknai sebagai suatu proses pengumpulan analisis dan penafsiran yang sistematis untuk menentukan sampai sejauh mana peserta didik mencapai tujuan pembelajaran seperti yang dinyatakan dalam kurikulum. Evaluasi kurikulum dimaksud untuk memeriksa kinerja kurikulum secara keseluruhan di tinjau dari berbagai kriteria. Indikator kinerja yang di evaluasi tidak hanya terbatas pasa efektvitas saja, namun juga relevansi, efesiensi profram. Penelitian ini menggunakan jenis penelitian kualitatif dengan menggunakan wawancara deskripsi sebagai teknik pengumpulan datanya. Hasil menunjukkan bahwa dalam penerapannya, guru masih mengalami kesulitan dalam proses kegiatan belajar karena kurang optimalnya pelatihan guru. pelatihan dalam penerapan kurikulum K13 dilaksanakan dalam waktu satu minggu, dan hanya beberapa guru saja yang mengikuti pelatihan sehingga tidak meratanya guru yang sudah mampu menerapkan kurikulum K13 dalam proses kegiatan mengajar di sekolah dasar.
\end{abstract}

Kata Kunci : Evaluasi, Kurikulum K13, Sekolah Dasar

Manazhim : Jurnal Manajemen dan Ilmu Pendidikan

Volume 2, Nomor 1, Februari 2020; 19-28

https://ejournal.stitpn.ac.id/index.php/manazhim 


\section{PENDAHULUAN}

Menurut Mudlofir ${ }^{1}$, kurikulum di tinjau dari segi bahasa berasal dari kata curir, dari bahasa yunani yang artinya tempat berpacu dalam sebuah perlombaan yang di lalui oleh para kompetitor. Konsekuensinya adalah setiap peserta wajib mematuhi aturan main dalam perlombaan. Istilah kurikulum pada awalnya berasal dari dunia olah raga pada zaman Romawi Kuno di Yunani, yang kemudian diadobsi ke dalam dunia pendidikan. Pengertian tersebut kemudian di gunakan dalam dunia pendidikan, dengan pengertian sebagai rencana dan pengaturan tentang sejumlah mata pelajaran yang harus di pelajari peserta didik dalam menempuh pendidikan di lembaga pendidikan.

Secara terminologi, istilah, kurikulum yang di gunakan dalam dunia pendidikan mengandung pengertian sebagai sejumlah pengetahuan atau mata pelajaran yang harus di tempuh atau di selesaikan siswa untuk mencapai satu tujuan pendidikan atau kompetensi yang di terapkan. Sebagai tanda atau bukti bahwa seseorang peserta didik telah mencapai standar kompetensi tersebut adalah dengan sebuah ijazah yang di berikan kepada peserta didik.

Dengan demikian, penerapan terhadap praktek pengajaran yaitu setiap siswa harus menguasai seluruh mata pelajaran yang diberikan dan menempatkan guru dalam posisi yang sangat penting dan menentukan, keberhasilan siswa di tentukan oleh seberapa jauh mata pelajaran tersebut di kuasainya dan biasanya di simbolkan dengan skor yang di peroleh setelah mengikuti suatu tes atau ujian.

Definisi kurikulum senantiasa berkembang terus sejalan dengan perkembangan teori dan praktik pendidikan. Pada saat sekarang istilah kurikulum memiliki empat di mensipengertian, satu dimensi dengan dimensi lainnya saling berhubungan. Menurut Depdiknas ${ }^{2}$, kempat dimensi kurikulum tersebut yaitu : 1). Kurikulum sebagai suatu ide / gagasan 2). Kurikulum sebagai suatu rencana tertulis yang sebenarnya merupakan perwujudan dari kurikulum sebagai suatu ide 3). Kurikulum sebagai suatu kegiatan yang sering pula disebut dengan istilah kurikulum sebagai suatu realita atau implementasi kurikulum. Secara teoritis dimensi kurikulum

${ }^{1}$ Ali Mudlofir, Aplikasi Pengembangan Kurikulum Tingkat Satuan Pendidikan dan Bahan Ajar dalam Pendidikan Agama Islam (Jakarta: PT Raja Grafindo Persada, 2011).

${ }^{2}$ Depdiknas, Kurikulum Tingkat Satuan Pendidikan (Jakarta: Dikmenum, 2008). 
ini adalah pelaksanaan dari kurikulum sebagai suatu rencana tertulis 4). Kurikulum sebagai suatu hasil yang merupakan konsekuensi dari kurikulum sebagai suatu kegiatan.

Evaluasi dimaknai sebagai suatu proses pengumpulan analisis dan penafsiran yang sistematis untuk menentukan sampai sejauh mana peserta didik mencapai tujuan pembelajaran seperti yang dinyatakan dalam kurikulum. Evaluasi kurikulum dimaksud untuk memeriksa kinerja kurikulum secara keseluruhan di tinjau dari berbagai kriteria. Indikator kinerja yang di evaluasi tidak hanya terbatas pasa efektvitas saja, namun juga relevansi, efesiensi profram. Pada bagian lain, dikatakan luas atau tidaknya suatu program evaluasi kurikulum. Apakah evaluasi tersebut di tujukan untuk mengevaluasi keseluruhan sistem kurikulum atau komponen komponen tertentu saja dalam sistem kurikulum tersebut. salah satu komponen kurikulum penting yang perlu dievaluasi adalah berkenaan dengan proses dan hasil belajar siswa.

Evaluasi kurikulum juga bervariasi, tergantung pada di mensi- dimensi yang menjadi fokus evaluasi. Salah satu dimensi yang sering mendapat sorotan adalah dimensi kuantistas dan kualistas. Insrumen yang di gunakan untuk mengevaluasi dimensi kuantitatif berbeda dengan dimensi kualitatif. Instrumen yang di gunakan untuk mengevaluasi dimensi kuantitatif, seperti tes standar, tes prestasi belajar dan lain - lain. Sedangkan, instrumen untuk mengevaluasi dimensi kualitatif dapat di gunakan, questionnare, interview dan catatan.

Menurut Kemdikbud ${ }^{3}$, ciri-ciri evaluasi dalam melaksanakan kurikulum 2013 sebagai berikut.

1. Belajar tuntas adalah peserta didik dapat mencapai kompetensi yang ditentukan asal komputer didik dapat mencapai kompetensi yang ditentukan, asalkan peserta didik mendapat bantuan yang tepat dan diberi waktu sesuai dengan yang dibutuhkan.

${ }^{3}$ Kemdikbud, Materi Pelatihan Guru Implementasi Kurikulum 2013: SD Kelas IV (Jakarta: Badan Pengembangan Sumber Daya Manusia Pendidikan dan Kebudayaan dan Penjaminan Mutu Pendidikan, 2013). 
2. Authentik memandang penilaian dan pembelajaran adalah merupakan dua hal yang saling berkaitan penilaian autentik harus mencerminkan masalah dunia nyata, bukan dunia sekolah. Menggunakan berbagai cara dengan kriteria holistik kompetensi untuk merefleksikan pengetahuan, keterampilan dan sikap.

3. Berkesinambungan penilaian dimaksudkan sebagai penilaian yang dilakukan secara terus-menerus dan berkelanjutan selama pembelajaran berlangsung. Tujuannya adalah untuk mendapatkan gambaran yang utuh mengenai perkembangan hasil belajar peserta didik memantau proses kemajuan dan perbaikan hasil menerus dalam bentuk Penilaian proses dan berbagai jenis ulangan secara berkelanjutan seperti ulangan harian ulangan tengah semester, ulangan akhir semester, dan ulangan kenaikan kelas.

4. Menggunakan teknik penilaian yang bervariasi berupa tertulis, lisan, produk, portofolio, unjuk kerja, projek pengamatan dan penilaian diri.

5. Berdasarkan acuan kriteria penilaian didasarkan pada ukuran pencapaian kompetensi ditetapkan. Kemampuan peserta didik tidak dibandingkan terhadap kelompoknya tetapi dibandingkan terhadap kriteria yang ditetapkan misalnya ketentuan-ketentuan belajar minimal KKM, yang ditetapkan oleh satuan pendidikan masing-masing dengan mempertimbangkan karakteristik kompetensi dasar yang akan dicapai daya dukung sarana dan guru, dan karakteristik peserta didik.

Implementasi Kurikulum 2013 tingkat SD masih dilaksanakan pada Kelas I dan Kelas VI. Kurikulum 2013 dilaksanakan untuk membentuk karakter dan keterampilan dari masing-masing peserta didik. Pemerintah memberikan sosialisasi selama implementasi Kurikulum 2013 berupa diklat untuk menunjang kelancaran implementasi Kurikulum 2013 dan supaya guru memperoleh wawasan mengenai Kurikulum 2013. 
Mulyasa $^{4}$ mengungkapkan Sosialisasi dalam implementasi kurikulum sangat penting dilakukan, agar semua pihak yang terlibat dalam implementasinya di lapangan paham dengan perubahan yang harus dilakukan sesuai dengan tugas pokok dan fungsinya masing-masing, sehingga mereka memberikan dukungan terhadap perubahan kurikulum yang dilakukan.

\section{METODE DAN PENDEKATAN PENELITIAN}

\section{Jenis Penelitian}

Penelitian ini menggunakan jenis penelitian kualitatif. Dalam penelitian ini peneliti mengumpulkan data deskriptif yang diperoleh dari pengumpulan data dengan melalui observasi, wawancara dan dokumentasi.

\section{Tempat Dan Waktu Penelitian}

Penelitian ini dilaksanakan di SD Darmawati Arief Jl. Beo Raya Blok E19 No. 9, RT.7/Rw.10, Kuta Baru, Kec. Ps. Kemis, Tangerang, Banten. 15560.

\section{HASIL DAN PEMBAHASAN}

Hasil data diperoleh dari wawancara dan observasi. Wawancara dengan kepala sekolah dan guru. dilakukan menggunakan panduan wawancara untuk mendapatkan informasi tentang Evaluasi Penerapan Pembelajaran K13. Hasil penelitian kami menunjukkan bahwa kesiapan guru hanya 80\%. Guru mengalami kesulitan dalam proses kegiatan belajar karena kurang optimalnya pelatihan guru. pelatihan dalam penerapan kurikulum K13 dilaksanakan dalam waktu satu minggu, dan hanya beberapa guru saja yang mengikuti pelatihan sehingga tidak meratanya guru yang sudah mampu menerapkan kurikulum K13 dalam proses kegiatan

${ }^{4}$ Mulyasa, Pengembangan dan Implementasi Kurikulum 2013 (Bandung: PT Remaja Rosdakarya, 2013). 
mengajar di sekolah dasar Darmawati Arief. Kepala sekolah Darmawati Arief merasa jika kurikulum K13 tidak cocok diterapkan di Sekolah Dasar. Karena peserta didik belum siap menerima kurikulum K13 secara utuh. Setelah pelatihan kepala sekolah dan guru memperhatikan kurikulum K13 tersebut tapi tidak sesuai dengan visi misi pada saat pelatihan.

Menurut buku Rencana pelaksaan tematik terpadu Perubahan kurikulum dari kurikulum 2006 ke kurikulum 2013 ini kiranya cukup relevan karena mutu pendidikan di Indonesia pada umumnya masih rendah dan cukup tertinggal dengan Negara - Negara maju lainnya. Seharusnya di Indonesia ini harus mempersiapkan dengan matang tentang perubahan kurikulum dan segala aspek sarana prasarananya juga.

Persiapan buku SD Dharmawati Arief mencapai 100\% dari pemerintah. Hal ini menunjukkan kesiapan buku K13 sudah terlaksana dengan baik untuk diterapkan dalam proses pembelajaran K13. Buku K13 mengamati beberapa tema-tema berbagai mata pelajaran menjadi satu kesatuan. Hasil wawancara dengan kepala sekolah menghasilkan informasi bahwa Sekolah telah menyediakan buku sesuai dengan jumlah siswa di SD Darmawati Arief. Pada penerapan kurikulum K13 ini Pemerintah juga memberikan buku tidak hanya untuk siswa tetapi untuk guru juga sebagai pedoman untuk kegiatan proses pembelajaran yang sesuai RPP.

Sumber belajar ditentukan sebagai informasi yang di sediakan dan disimpan dalam berbagai bentuk media, yang dapat membantu siswa dalam belajar sebagai perwujudan dari kurikulum. Bentuknya tidak terbatas dalam bentuk cetakan, video, format yang dapat di gunakan peserta didik dharmawati Arief. Sadiman, sumber belajar, yang dapat di gunakan untuk belajar, dapat di gunakan untuk orang, benda, pesan, bahan, teknik dan latar. Buku yang berisi segala macam buku yang dapat dibaca secara mandiri oleh peserta didik dapat di sebut dengan sumber ajar.

Kesiapan sarana dan prasarana sudah mencapai 80\%. Di sekolah dasar darmawati Arief mengalami kekurangan sarana dan prasarana yang sesuai dengan proses pembelajaran kepala sekolah mengatakan kurang diperhatikan pemerintah dalam sarana dan prasarana di SD Darmawati Arief. Kondisi perpustakaan juga sangat baik, semua buku-buku yang diperlukan Hampir ada, tetapi ada saja yang 
kurang sehingga perlu untuk penambahan titik penambahan buku agar tercapainya proses kegiatan belajar secara maksimal. Dan media pembelajaran harus lebih diperhatikan khususnya sekolah dasar swasta dibandingkan negeri agar terciptanya lingkungan pendidikan yang tentram dan kondusif.

Sarana prasarana penunjang kurikulum 2013 harus bener - bener di pikiran sebelum kurikulum di laksanakan. Contohnnya pengadaan buku, membahas buku materi harus sudah sampai di tangan guru pengajar sebelum kurikulum di laksanakan, agar guru bisa membuka kembali apa yang ada di buku dan bisa membuat alat peraganya unutk kegiatan proses pembelajaran. Agar setiap materi yang dai ajarkan oleh gurunya paham karena tidak semua peserta didik langsung paham apa yang sedang di pelajari. Contoh anak SD kelas 1-3 itu masih berpikir kongkrit sedangkan anak SD kelas 4-6 itu sudah mulai berpikir abstrak.

Kondisi RPP sudah mencapai 90\%. Dalam menerapkan RPP sesuai dengan modul yang sudah ada sebagai tujuan pembelajaran. Hal ini menunjukkan bahwa RPP selalu digunakan dalam proses pembelajaran secara rutin untuk keberhasilan tujuan pembelajaran. Setiap pembelajaran harus sesuai RPP yang telah telah dibuat.dalam menyusun silabus dan RPP melalui pelatihan - pelatihan yang di lakukan dinas kementrian pendidikan dan kebudayaan.

Pada pembelajaran guru harus sudah dapat menyusun silabus mata pelajaran yang akan di ajarkan. Diharapkan guru telah paham, mampu menyusun RPP dengan baik dan benar agar terkasanakan proses pemebajaran. Di buku ini ada contoh dalam pembuatan RPP sehingga guru bisa nyusun dengan mudah. Komponen RPP, sebagai berikut : (1). Identitas sekolah (2). Identitas mata pelajaran. (3). Kelas/semester (4). Materi pokok (5). Alokasi waktu (6). Kompetensi inti (7). Kompetensi dasar (8). Tujuan pembelajaran (9). Materi pembelajaran (10). Meteode pembeljaran (11). Media $_{s}$ alat dan sumber (12). Langkah - langkah kegiatan pemelajaran (13). Penilaian

Proses pembelajaran adalah proses pembelajaran di SD dan mengamati sudah mencapai $80 \%$ dalam pembelajaran menggunakan tema atau penerapan kurikulum K13. Di sekolah dasar ini dalam pembelajaran tema memberikan pengaruh positif bagi siswa. Siswa menjadi lebih aktif dan kritis dalam kegiatan belajar. Dengan menggunakan pendekatan saintifik pembelajaran menjadi lebih bermakna dan 
menarik siswa menjadi lebih antusias dan bersemangat karena menggunakan alat peraga dalam proses pembelajarannya peserta didik kelas 1-3 masih berpikir konkrit jadi setiap kegiatan belajar peserta didik harus benar-benar nyata. Alat peraga Bisa dilihat diraba dan diterawang contoh tema 1 belajar materi matematika tentang bangun ruang kita sebagai guru harus membawa alat peraga berupa balok, kubus, bola yang dibuat dari kertas karton Sehingga peserta didik kelas 1-3 memahami materi yang disampaikan oleh guru.

Sedangkan peserta didik kelas 4-6 atau kelas tinggi sudah mulai bisa berpikir abstrak tidak menggunakan alat peraga pun ia bisa mengerti apa yang disampaikan oleh gurunya contoh belajar matematika peserta didik langsung mengerti bahwa ia sedang belajar pecahan. Dalam proses pembelajaran diharapkan agar peserta didik mendapat pelayanan yang bersifat perbaikan pengayaan dan proses percepatan sesuai dengan potensi. Pada pendekatan saintifik mempunyai lima komponen yaitu mengamati, menanya, mencoba, menalar dan mengomunikasikan.

Penilaian di SD Darmawati Arief sudah mencapai 95\%. Hal ini menunjukkan cara penilaian melalui faktor utama sikap di SD adalah faktor sosial dan spiritual sikap spiritual yaitu dalam pembelajaran ibadah Apakah anak beriman dan bertakwa kepada Tuhan Yang Maha Esa. Sikap sosial yaitu berakhlak mulia sehat mandiri dan demokratis ia bertanggungjawab. Pada sikap sosial ini ketika peserta didik bersosialisasi dengan satu sama lain sehingga tercipta lingkungan yang baik untuk perkembangan peserta didik. Pada penilaian sikap di atas dapat dilihat bahwa sikap yang mendapatkan nilai A itu tergantung pada penilaian percaya diri baik dan pengetahuannya sedangkan siswa yang mendapatkan nilai B itu tergantung pada penilaian percaya diri, pengetahuan, dan sikapnya tetapi kurang.

Respon siswa dalam pelaksanaan kurikulum 2013 sangat baik mencapai 80\% sehingga terciptanya kegiatan pembelajaran yang aktif. Aktifan dalam proses pembelajaran ini sangat berarti karena keaktifan peserta didik mempengaruhi apakah siswa paham atau tidak terhadap materi yang di sedang ajarkan, dengan menggunakan buku tematik atau buku betema.

Banyaknya respon positif dan negatif datang dari para siswa dan para guru dalam pelaksanaan kurikulum 2013. Didalam kurikulum 2013 siswa di suruh untuk 
mencari materi sendiri melalui internet karena materi atau buku-buku tidak tersediadi sekolahan. Menjadikan para siswa tertekan dengan diadakannya atau masih dilanjutkannya kurikulum 2013 ke depannya. Banyaknya tugas yang membebani siswa menjadikan orang tua mereka menjadi tersisksa contohnya saja ketika anak harus mengerjakan soal.

Hasil belajar mencapai $90 \%$. Dari hasil kegiatan pembelajaran kurikulum 2013 sangat baik jadi di SD Dharmawati Arief proses pembelajaran 2013 cukup berhasil tetapi ada sebagian siswa yang tidak paham tentang pembelajaran 2013 yang bertema ini. Jadi membutuhkan bimbingan lebih dalam mencapai proses pembelajaran yang lebih maksimal lagi. Di harapkan guru lebih aktif dalam membina anak didiknya. Guru bisa membuka les di rumah atau di sekolah untuk menambah ilmu - ilmu yang belum dapat di sekolah atau mengulang lagi materi yang sudah di ajarkan di sekolah. Sehingga tercapainya proses pembelajaran yang maksimal. Guru juga bisa mengadakan ulangan setiap minggu sekali. Jika belum sesuai kkm anak tersebut akan di berikan remedial- remedial, tugas-tugas agar dapat memenuhi sesuai kkm sehingga anak tersebut mendapatkan nilai yang di harapkan.

\section{KESIMPULAN}

Kurikulum adalah sebagai rencana dan pengaturan tentang sejumlah mata pelajaran yang harus di pelajari peserta didik dalam menempuh pendidikan di lembaga pendidikan. Evaluasi dimaknai sebagai suatu proses pengumpulan analisis dan penafsiran yang sistematis untuk menentukan sampai sejauh mana peserta didik mencapai tujuan pembelajaran.

Hasil data diperoleh dari wawancara dan observasi. Wawancara dengan kepala sekolah dan guru dilakukan menggunakan panduan wawancara untuk mendapatkan informasi tentang Evaluasi Penerapan Pembelajaran K13. Hasil penelitian kami menunjukkan bahwa kesiapan guru hanya 80\% karena kurangnya pelatihan- pelatihan. Persiapan buku SD Dharmawati Arief mencapai 100\% dari pemerintah, tetapi bahan ajar atau sarana prasarana hanya $80 \%$ yang lain kurang di persiapka sehingga kita sebagai guru harus membuat sendiri. Untuk kesiapan fasilitas 
hampir $80 \%$. Kondisi RPP mecapai $90 \%$ dan dalam kegaiatan proses pembelajaran di SD dharmawati Arief sudah mencapai $80 \%$ dalam pembelajaran menggunakan tema atau penerapan kurikulum K13. Penilaian di SD sudah mencapai 95\%. Hal ini menunjukkan cara penilaian melalui faktor utama sikap di SD adalah faktor sosial dan spiritual. Respon peserta didiknya juga sangat baik tetapi hasil belajarnya kurang baik.

\section{DAFTAR PUSTAKA}

Ali Mudlofir, Aplikasi Pengembangan Kurikulum Tingkat Satuan Pendidikan dan Bahan Ajar dalam Pendidikan Agama Islam (Jakarta: PT Raja Grafindo Persada, 2011).

Depdiknas. Pedoman umum pengembangan Baban Aja. Jakarta : Ditjen Dikdasmenum,2004.

Depdiknas, Kurikulum Tingkat Satuan Pendidikan (Jakarta: Dikmenum, 2008).

Kemdikbud, Materi Pelatihan Guru Implementasi Kurikulum 2013: SD Kelas IV (Jakarta: Badan Pengembangan Sumber Daya Manusia Pendidikan dan Kebudayaan dan Penjaminan Mutu Pendidikan, 2013).

Mulyasa, Pengembangan dan Implementasi Kurikulum 2013 (Bandung: PT Remaja Rosdakarya, 2013).

Regina Lichteria Panjaitan. (2004). Evaluasi Pembelajaran Sd Berdasarkan Kurikulum 2013. Julia. UPI SUMEDANG PRESS.

Sa'ud, udin Syaefudin. inovasi pendidikan. Bandung : alfabeta, 2009.

Shobirin, Ma'as. Konsep dan Implementasi kurikulum 2013 di Sekolah Dasar/ oleh Ma'as Shobirin.-Ed.1, Cet. 1-Yogyakarta: Deepublish, juni 2016.

Sudjana, Nana. 2008. Pembinaan dan pengembangan kurikulum di sekola. Bandung: Sinar Baru Algensindo.

Sri budiani, sudarmin \& rodia syamwil “ Evaluasi implementasi kurikulum k13 di sekolah pelaksana mandiri “ / IJCET 6 (1) (2017) : 45-57. [http://dx.doi.org/10.15294/ijcet.v6il.15998]

http://mbscenter.or.id/site/page/id/386/page_action/viewdetail 